\title{
POLA FRIEZE GROUP PADA GERAKAN TARI BUYUNG KUNINGAN
}

\author{
Lia Andriani' ${ }^{1)}$, Arif Muchyidin ${ }^{2)}$ \\ ${ }^{1), 2)}$ IAIN Syekh Nurjati Cirebon, J1. Perjuangan,Cirebon, Indonesia \\ liaandriani@syekhnurjati.ac.id,muchyidin@syekhnurjati.ac.id
}

\begin{abstract}
Buyung dance is rarely displayed and has begun to be unknown to the public. Also, children, today prefer foreign culture and dance. As a result, the existence of Buyung dance is only limited to recognition, without the benefits that can be felt. The absence of written guidelines in each of the Buyung dance movements is very interesting for researchers to analyze the relationship of the Buyung dance movements with mathematics. This type of research used in this study is qualitative research. In qualitative research, the instrument is the researcher himself and cannot be replaced by others. Data collection techniques used in this study through the method of observation, interviews, and documentation. Every hand movement of the dancers and movements between dancers to one another makes the movements of the dances neat and attractive following the Frieze Group, with four frieze patterns found in the dances of the pitchers.
\end{abstract}

Keywords: buyung dance, qualitative research, the Frieze Group

\begin{abstract}
Abstrak
Tari buyung sudah jarang ditampilkan dan sudah mulai tidak dikenal oleh masyarakat. Selain itu, anak zaman sekarang lebih memilih budaya dan tarian asing. Akibatnya, keberadaan tari buyung hanya sebatas pengakuan, tanpa dapat dirasakan manfaatnya. Belum adanya panduan tertulis dalam setiap gerakan tari buyung sangat menarik peneliti untuk menganalisa keterkaitan gerakan tari buyung dengan matematika. Jenis penelitian yang digunakan pada penelitian ini adalah penelitian kualitatif. Pada penelitian jenis kualitatif, instrumen yaitu peneliti itu sendiri dan tidak dapat digantikan oleh orang lain. Teknik pengumpulan data yang digunakan dalam penelitian ini melalui metode observasi, wawancara dan dokumentasi. Setiap gerakan tangan para penari dan gerakan antara penari satu dengan yang lainnya membuat gerakan tari buyung menjadi rapih dan menarik ternyata sesuai dengan Grup Frieze, dengan empat pola frieze terdapat pada tarian buyung.
\end{abstract}

Kata Kunci : tari buyung, penelitian kualitatif, Grup Frieze

Cara Menulis Sitasi: Andriani, L., \& Muchyidin, A. (2020). Pola Frieze Group pada Gerakan Tari Buyung Kuningan. Jurnal Edukasi dan Sains Matematika (JES-MAT),6 (2), 81-100.

\section{PENDAHULUAN}

Selain sebagai tempat unuk bersosialisai bagi siswa, pembelajaran di sekolah juga bertujuan untuk membentuk karakter siswa (Fitriah, Muchyidin, \& Sahrodi, 2015). Hal ini sesuai dengan tujuan pendidikan karakter dalam kurikulum 2013 yaitu untuk mengembangkan potensi peserta didik agar menjadi manusia berbakti baik, berpikir baik, dan berperilaku baik, membangun bangsa yang berkarakter pancasila dan mengembangkan potensi warga negara agar memiliki sikap percaya diri, bangga pada bangsa dan negaranya serta mencintai umat manusia (Munjiatun, 2018; Sahroni, 2017; 
Sumaryati, 2016). Salah satu faktor pembentuk karakter siswa adalah nilai-nilai luhur yang terdapat pada kearifan lokal yang dimiliki siswa itu sendiri. Akan tetapi, nilai budaya dan kearifan lokal bangsa indonesia mulai terkikis oleh deras arus modernisasi globalisasi (Muchyidin, 2016; Nahak, 2019; Sutarto, 2016).

Pendidikan karakter bisa diwujudkan dengan mengembalikan pendidikan budi pekerti yang bisa berdampak pada akhlak sosial yang mengandung keluhuran nilainilai kearifan lokal. Atas dasari itulah, pemerintah Provinsi Jawa Barat meluncurkan konsep baru untuk pendidikan karakter yang dinamai Jabar Masagi. Program Jabar Masagi adalah program pendidikan berbasis budaya Jawa Barat. Jabar Masagi adalah pendidikan budi pekerti yang berdampak pada akhlak sosial yang mengandung keluhuran nilai-nilai kearifan lokal yang sesuai dengan kebutuhan dan konteks budaya masingmasing wilayah di Jawa Barat (Lukihardianti, 2018).

Selama ini pendidikan dan kebudayaan dinilai sebagai ilmu pengetahuan yang tidak saling berkaitan padahal pendidikan bisa menyatu dengan budaya (Amalia, Muchyidin, \& Izzati, 2019; Fauzi, 2018; Thonthowi, 2008). Salah satu ontohnya adalah tari buyung yang berasal dari Kuningan, Jawa Barat. Tari buyung merupakan kesenian sunda yang dapat dijadikan sebagai pembelajaran matematika. Jika dicermati lebih dalam, tari buyung memiliki banyak konsep matematika, seperti teori grup dan geometri transformasi.

Budaya tari buyung sudah jarang ditampilkan dan sudah mulai tidak dikenal oleh masyarakat. Selain itu, anak zaman sekarang lebih memilih budaya dan tarian asing. Akibatnya, keberadaan tari buyung hanya sebatas pengakuan, tanpa dapat dirasakan manfaatnya (Abriyanti, 2019; Royyani, 2008). Berdasarkan hasil wawancara pra penelitian yang dilakukan peneliti pada hari Minggu, 11 November 2018 kepada narasumber yaitu Ibu Emalia Djatikusumah selaku koreografer sekaligus pelopor tari buyung.

"Tari buyung adalah salah satu tarian utama dan wajib ditampilkan dalam pegelaran seren tahun. Tari buyung terdapat ketukan dalam berpindahnya dari gerakan satu ke gerakan lainnya berdasarkan musik pengiring. Tari buyung juga sebenarnya terbagi menjadi 5 formasi utama yang tidak boleh ditinggalkan yaitu jala sutra, nyakra bumi, bale bandung, medang kamulan dan nugu telu. Formasi tersebut memiliki bermacam-macam bentuk seperti bentuk bulan sabit, lingkaran dan lain sebagainya. Tidak banyak yang tahu bahwa selain hal itu setiap gerakan dan pola pada tari mengikuti alur kebiasaan masyarakat dahulu dan musik pengiring."

Berdasarkan hasil wawancara tersebut, dapat disimpulkan bahwa setiap gerakan pada tarian buyung tidak memiliki panduan tetap secara tertulis disetiap gerakan yang ditampilkan. Para penari hanya mengikuti alur musik pengiring dan filosofi tarian tersebut. Meskipun begitu, jika dilihat secara seksama, gerakan pada tari buyung memiliki konsep matematika seperti bidang geometri, transformasi geometri dan hitungan serta pengukuran yang dilakukan penari dalam melakukan tarian buyung. Selain itu, dalam setiap gerakan dan formasi tari buyung juga memiliki makna filosofi tersendiri. Salah satu contohnya gerakan tangan bergandengan sejajar yang mempunyai makna langkah seirama, seia sekata tidak 
membeda-bedakan antara perbedaan agama, bangsa, etnis, suku, ras semuanya ciptaan tuhan. Dengan dijalin rasa saling tolerasi dan rasa saling menghormati.

Beberapa penelitian yang mengaitkan tarian dengan matematik sudah banyak dilakukan. Misalnya Oktavianto dkk (2018) yang mengkaji pola Frieze Group pada Tari Saman, Sandhi dkk (2018) yang mengkaji geometri (sudut dan bidang) pada Tarian Jejer Jaran, atau penelitian yang dilakukan oleh Desmawati (2018) yang menemukan adanya geometri bidang dan geometri transformasi pada gerak Tari Sigeh Penguten Lampung. Berbeda dengan penelitian yang sudah ada, penelitian yang peneliti lakukan adalah mengkaji pola Frieze Group pada gerakan (tangan dan kaki) Tari Buyung dan makna filosofis yang terkandung di dalamnya.

Belum adanya panduan tertulis dalam setiap gerakan tari buyung sangat menarik peneliti untuk menganalisa keterkaitan gerakan tari buyung dengan matematika berdasarkan video yang ada. Kajian ini erat juga kaitannya dengan program yang diluncurkan oleh pemerintahan Provinsi Jawa Barat yaitu Jabar Masagi. Jabar Masagi merupakan salah satu program pemerintah Provinsi Jawa Barat periode 2018 - 2023 dengan oreintasi pada pendidikan karakter. Inti dari nilai-nilai yang dikembangkan program Jabar Masagi akan bermuara pada jati diri Sunda yaitu cageur, bageur, bener, pinter, dan singer. (Suherman, 2018). Permasalahan ini sangat menarik untuk diangkat ke dalam suatu penelitian yang akan peneliti lakukan yaitu tari buyung dan unsur matematika yang ada dalam tari buyung.

\section{LANDASAN/KAJIAN TEORI Tari Buyung Kuningan}

Tari buyung merupakan tarian khas masyarakat Cigugur, Kabupaten Kuningan. Tarian ini merupakan tarian utama dalam upacara seren taun di Desa Cigugur Kuningan Jawa Barat (Suharyanto, 2018). Tarian ini menceritakan tentang gadis-gadis Desa Cigugur yang sedang mengambil air ke sungai (Pemerintah Kabupaten Kuningan, 2019).

Tari buyung merupakan Tarian adat sunda yang mencerminkan masyarakat sunda dalam mengambil air. Di samping itu, arti buyung merupakan sejenis alat yang terbuat dari logam maupun tanah liat yang sering dipergunakan oleh sebagian masyarakat wanita desa di jaman dahulu untuk mangambil air di sungai, danau atau kolam. Tari buyung awalnya menceritakan bagaimana para gadis desa yang turun ke sungai di pancoran ciereng dengan menggunakan buyung. Buyung sendiri terbuat dari gerabah yang dibentuk seperti gentong lalu dibakar dengan suhu maksimum $100 \mathrm{oC}$ untuk menghasilkan buyung yang kuat (Suharyanto, 2018). Kebiasaan mengambil air dengan buyung sudah lama dilakukan oleh masyarakat khususnya para wanita muda Kuningan Desa Cigugur dengan perilaku masyarakatnya yang suka menolong, hidup bergotong royong tanpa memandang latar belakang status sosial maupun kepercayaan mereka. Kini, kebiasaan mereka sudah menghilir, terhayut seiring berpacunya roda-roda jaman yang terus bergulir mengikuti arus teknologi yang semakin berkembang. Yang tertinggal hanyalah kenangan dalam cerita-cerita nostalgia.

Tarian ini tercipta oleh Emalia Djatikusumah (Reinha, 2019; Widi, 2019). Tarian hasil kreasi dari Emalia 
Djatikusumah istri dari sesepuh adat yang tak lain adalah Djatikusumah pada tahun 1969. Pada tahun 1969-an kebiasaan yang dilakukan masyarakat wanita desa pada jaman dahulu dapat tergambar dan telihat dalam tari buyung Kuningan.

Tari ini banyak memperoleh apresiasi dari masyarakat sekitar dan para wisatawan mancanegara. Hal ini dikarenakan beberapa gerakan tampak tidak umum bagi masyarakat yang sudah menekuni tari buyung ini. Penari terdiri dari beberapa wanita tetapi terkadang bisa lebih tergantung seberapa besar upacara yang dilakukan. Penari biasanya memakai kebaya, selendang yang diikat dipinggang, kain batik yang dilipat diikat dikepala, rambut disanggul, serta buyung yang diletakkan dikepala dan kendi dipegang (Suharyanto, 2018). Agar lebih jelas penulis mengilustrasikan pakaian yang dikenakan penari menggunakan Gambar 1 sebagai berikut.

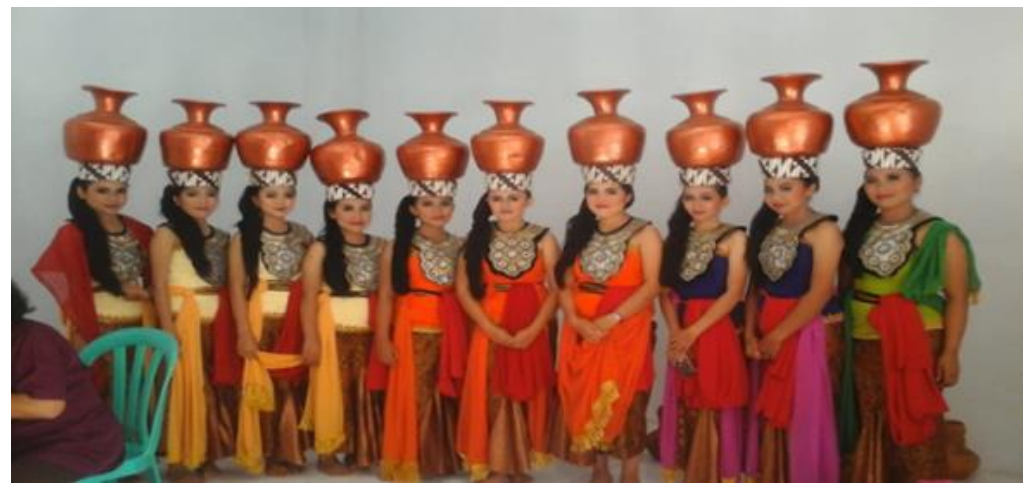

Gambar 1. Kostun Penari Buyung

Penampilan para penari bukan satusatunya daya tarik penonton tetapi tari buyung memiliki gerakan-gerakan yang khas. Gerakan yang memikat dalam tarian ini saat penari menari di atas kendi dengan menjunjung buyung. Gerakan tariannyapun cenderung lemah lembut. Siapapun yang akan melihatnya pasti akan kagum. Gerakan tari tersebut berarti nyuhun dan erat dengan perumpamaan "dimana bumi dipijak di situ langit dijunjung" (Suharyanto, 2018). Gerakan tari tersebut seperti pada Gambar 2.

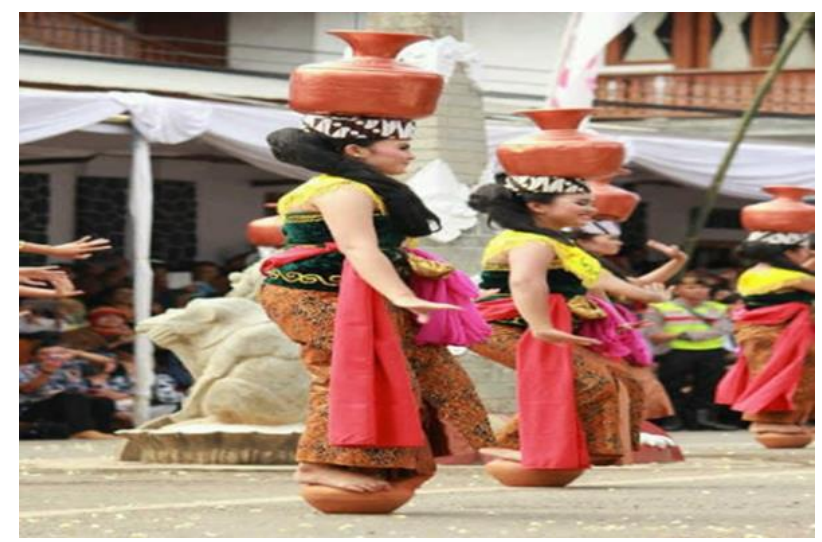

Gambar 2. Penari Menari di Atas Kendi 


\section{Frieze Group}

Berdasarkan definisi yang diambil dari Drager (2010) Sebuah grup isometri diskrit $\mathrm{G}$ merupakan sebuah Grup Frieze jika semua vektor dalam latis adalah segaris (Collinear). Simetris-simetris grup tersebut disebut pola-pola Frieze. Jika melakukan konjugasi pada $\mathrm{G}$ dengan operasi rotasi maka memperoleh grup yang secara geometris isomorfis pada arah $\mathrm{x}$ positif. Pola Frieze adalah pola-pola berulang yang dibentuk oleh simetri satu arah. Simetrisimetri tersebut adalah translasi, rotasi, refleksi, atau cermin geser.

Menurut Umble (2014) frieze group adalah kelompok pola simetri. Dari beberapa pola dapat dikelompokkan kedalam tujuh macam grup frieze tersebut yaitu:

1. Pola $1(\mathrm{~F} 1)$

Pada grup simetri di pola 1 hanya terdiri dari translasi. Misalkan adalah sebuah translasi maka grup pada pola 1 dapat ditulis $F 1=\left\{\tau^{n} \mid n \in \mathbb{Z}\right\}$. Grup F1 diilustrasikan seperti pada Gambar 3 berikut:

\section{FFFFFFFFF}

Gambar 3. Pola 1

2. Pola $2(\mathrm{~F} 2)$

Grup simetri pola 2 seperti pada pola 1 namun isometri yang digunakan adalah glide / refleksi geser. Misalkan $Y$ adalah glide/refleksi geser maka gup pola 2 dapat ditulis $F_{2}=\left\{\gamma^{n} \mid n \in \mathbb{Z}\right\}$. grup $\mathrm{F}_{2}$ dapat diilustrasikan Gambar 3 berikut:

\section{$\begin{array}{lllll}\mathrm{F} & \mathrm{F} & \mathrm{F} & \mathrm{F} & \mathrm{F}\end{array}$ E E E E E}

Gambar 4. Pola 2
3. Pola 3 (F3)

Grup simetri untuk pola 3 dibangun oleh translasi dan refleksi terhadap garis vertikal. Misalkan $\tau$ suatu translasi dan $\sigma$ suatu refleksi, maka grup pola 3 dapat ditulis

$$
F 3=\left\{\tau^{n} \sigma^{m} \mid n \in \mathbb{Z}, m=0 \text { atau } 1\right\}
$$

Grup F3 dapat diilustrasikan pada Gambar 5 berikut:

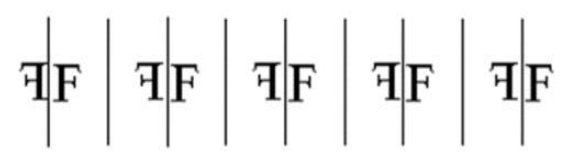

Gambar 5. Pola 3

4. Pola $4(\mathrm{~F} 4)$

Pada pola 4, grup simetri $\mathrm{F}_{4}$ dibangun oleh translasi dan rotasi $180^{\circ}$ dengan pusat $\mathrm{p}$ yaitu titik antara dua translasi. Misalkan $\tau$ suatu translasi dan $\rho$ adalah rotasi $180^{\circ}$ maka $\mathrm{F}_{4}$ ditulis

$F 4=\left\{\tau^{n} \rho^{m} \mid n \in \mathbb{Z}, m=0\right.$ atau 1$\}$

Grup $\mathrm{F}_{4}$ dapat diilustrasikan seperti pada Gambar 6 berikut:

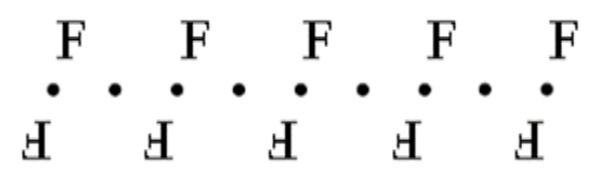

Gambar 6. Pola 4

5. Pola 5 (F5)

Grup simetris $F_{5}$ untuk pola 5 dibentuk oleh glide/refleksi geser dan rotasi $180^{\circ}$ maka grup untuk pola 5 dituliskan

$F 5=\left\{\gamma^{n} \rho^{m} \mid n \in \mathbb{Z}, m=0\right.$ atau 1$\}$

Grup $\mathrm{F}_{5}$ dapat diilustrasikan seperti pada Gambar 6 berikut:

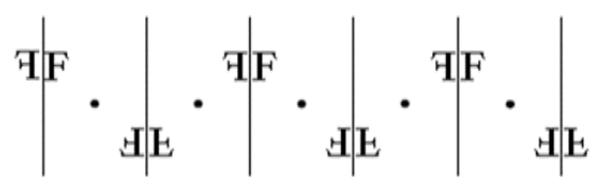

Gambar 7. Pola 5 
6. Pola $6(\mathrm{~F} 6)$

Grup simetris F6 untuk pola 6 dibentuk oleh translasi dan refleksi terhadap garis horizontal. Jika $\tau$ adalah suatu translasi dan $\sigma$ adalah refleksi terhadap garis horizontal, maka grup F6 dapat ditulis

$$
F 6=\left\{\tau^{n} \sigma^{m} \mid n \in \mathbb{Z}, m=0 \text { atau } 1\right\}
$$

Grup F6 dapat diilustrasikan seperti pada Gambar 8 berikut:

\begin{tabular}{ccccc}
$\mathrm{F}$ & $\mathrm{F}$ & $\mathrm{F}$ & $\mathrm{F}$ & $\mathrm{F}$ \\
\hline $\mathrm{E}$ & $\mathrm{E}$ & $\mathrm{E}$ & $\mathrm{E}$ & $\mathrm{E}$
\end{tabular}

Gambar 8. Pola 6

7. Pola 7 (F7)

Grup simetri F7 untuk pola 7 dibentuk oleh translasi, refleksi horizontal dan refleksi vertikal. Jika $\tau$ adalah suatu translasi, $\sigma_{1}$ suatu refleksi horizontal, dan $\sigma_{2}$ adalah refleksi vertikal maka grup F7 dapat dituliskan sebagai berikut:

$$
\begin{aligned}
& F 7= \\
& \left\{\tau^{n} \sigma_{1}^{m} \sigma_{2}^{k} \mid n \in \mathbb{Z}, m, k=0 \text { atau } 1\right\}
\end{aligned}
$$

Grup $\mathrm{F}_{7}$ dapat diilustrasikan seperti pada Gambar 9 berikut:

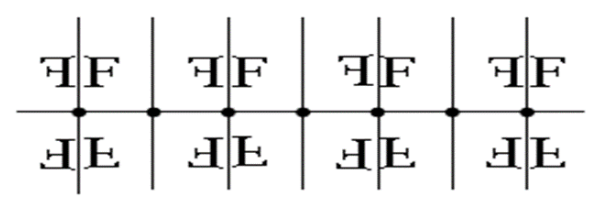

Gambar 9. Pola7

Seorang ahli matematika bernama John Conway memberi nama untuk setiap elemen grup frieze berdasarkan langkah kaki (Drager, 2010), perhatikan gambar berikut:
1. Pola F1 (Hop)

Pola F1 tidak memiliki isometri selain translasi. Pada Gambar 10 memperlihatkan pola F1.

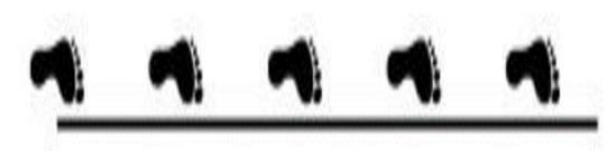

Gambar 10. Hop

2. Pola F2 (Step)

Pola F2, seperti diperlihatkan dalam Gambar 11, terdapat translasi dan cermin geser (glide reflection).

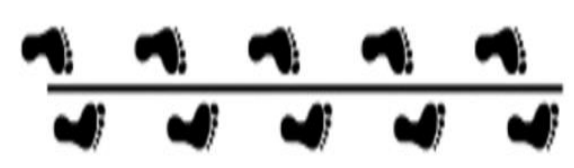

Gambar 11. Step

3. Pola F3 (Sidle)

Pola F3 memiliki refleksi yang sumbu simetrinya sejajar dengan arah translasi. Gambar 11 memperlihatkan pola F3 terdapat translasi dan refleksi secara vertikal.

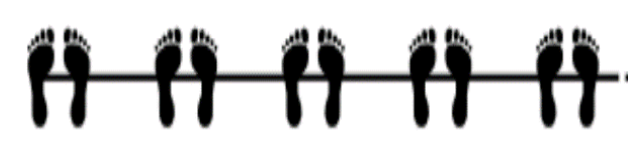

Gambar 12. Sidle

4. Pola F4 (Spinning Hop)

Pada pola F4 terdapat translasi dan rotasi $180^{\circ}$, seperti diperlihatkan dalam Gambar 12 berikut:

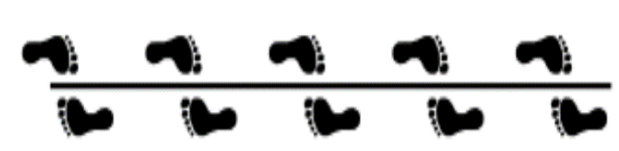

Gambar 12. Spinning Hop 
5. Pola F5 (Spinning Sidle)

Jika sebuah pola memiliki simetri yang berupa translasi, cermin geser, dan rotasi $180^{\circ}$, seperti diperlihatkan dalam Gambar 13, maka pola tersebut disebut pola F5.

\section{$n_{u} n_{u} n_{0} n^{u} n^{u}$}

Gambar 13. Spinning Sidle

6. Pola F6 (Jump)

Pola F6 memuat translasi dan refleksi secara horisontal seperti pada Gambar 14 berikut:

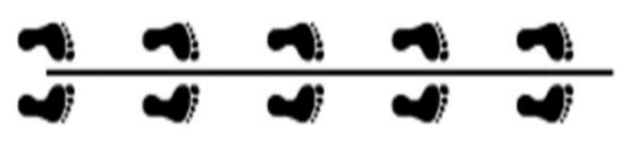

Gambar 14. Jump
7. Pola F7 (Spinning Jump)

Pada pola F7 terdapat semua pola yang ada pada F1-F6, yakni translasi, refleksi vertikal dan refleksi horisontal, serta rotasi.

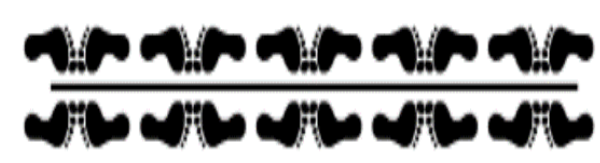

Gambar 15. Spinning Jump

atas, mengikuti langkah yang diperkenalkan oleh Umble \& Han (2014) berikut.

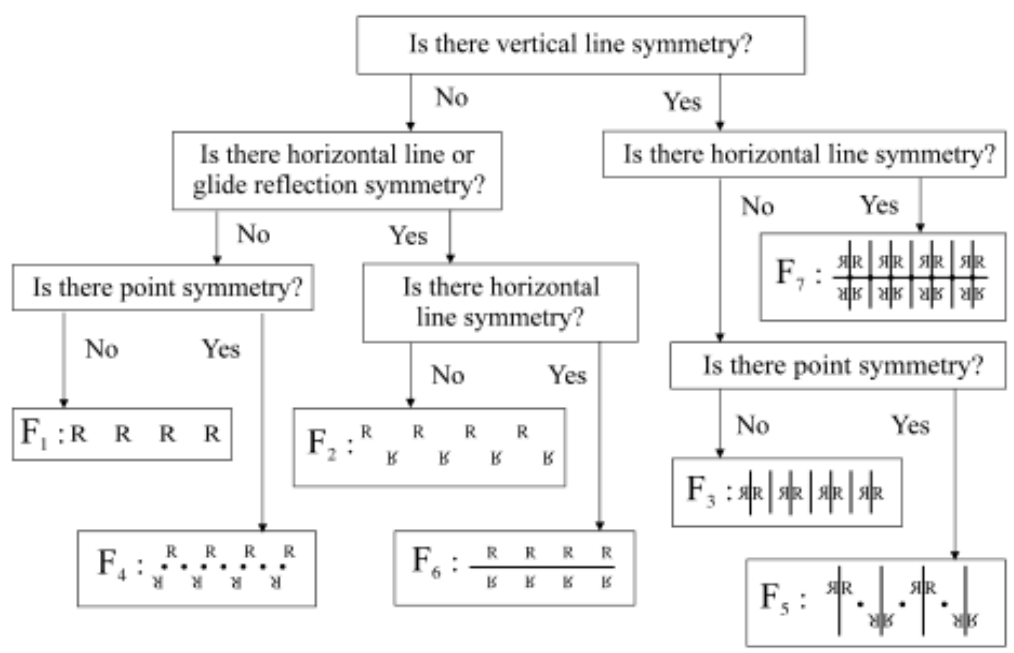

Gambar 16. Alur mengidentifikasi Anggota Frieze Group

\section{METODE PENELITIAN}

\section{Jenis Penelitian}

Jenis penelitian yang digunakan pada penelitian ini adalah penelitian kualitatif. Menurut Albi Anggito \& Johan Setiawan (2018), penelitian kualitatif adalah pengumpulan data pada suatu latar alamiah dengan maksud menafsirkan fenomena yang terjadi. Metode tersebut menurut Meolong (2017), adalah data yang dikumpulkan berupa kata-kata, gambar, dan bukan angka-angka kemudian dijelaskan agar dapat digambarkan. peneliti langsung turun ke lapangan, mempelajari suatu proses atau penemuan alamiah melalui proses, mencatat, menganalisa, manafsirkan 
dan melaporkan serta menarik kesimpulankesimpulan dari proses tersebut.

\section{Waktu dan Tempat Penelitian}

Tempat penelitian dilakukan di Paseban Tripancatunggal Kelurahan Cigugur Kecamatan Cigugur Kabupaten Kuningan, karena pelakon tari buyung Kuningan hanya di Paseban Tripancatunggal Cigugur yang masih melestarikannya sampai sekarang. Tempat ini sudah terkenal di Kuningan hingga luar daerah Kuningan, bahkan tempat tersebut setiap tahunnya menggelar tari buyung pada acara seren taun Penelitian dilakukan selama tiga bulan tertanggal dari bulan Februari 2019 sampai Mei 2019.

\section{Target/Subjek Penelitian}

Target/subjek penelitian adalah Ibu Emalia Djatikusumah selaku koreografer sekaligus pelopor tari buyung. Dipilihnya Ibu Emalia Djatikusumah sebagai target penelitian karena selain pelopor, beliau juga merupakan tokoh yang masih melestarikan tari buyung di Kuningan.

\section{Prosedur}

Menurut Sugiyono (2015), terdapat tiga tahap utama dalam penelitian kualitatif, yaitu: tahap deskripsi atau tahap orientasi (peneliti mendeskripsikan apa yang dilihat, didengar dan dirasakan), tahap reduksi (peneliti mereduksi segala informasi yang diperoleh pada tahap pertama untuk memfokuskan pada masalah tertentu), dan tahap seleksi (peneliti menguraikan fokus yang telah ditetapkan menjadi lebih rinci kemudian melakukan analisis secara mendalam tentang fokus masalah).

\section{Data, Intrumen, dan Teknik Pengumpulan Data}

Instrumen penelitian kualitatif merupakan alat yang dipakai untuk mengumpulkan data. Pada penelitian jenis kualitatif, instrumen yaitu peneliti itu sendiri dan tidak dapat digantikan oleh orang lain. Data dikumpulkan peneliti secara verbal serta diperkaya dari penglihatan, pendengaran, dan penghayatan dari peneliti mengenai gerakan tari buyung Kuningan.

Teknik pengumpulan data yang digunakan dalam penelitian ini melalui metode-metode berikut:

1. Observasi

$$
\text { Menurut Bungin }
$$

menyatakan observasi atau pengamatan adalah kemampuan seseorang untuk menggunakan pengamatan melalui hasil kerja pancaindra mata serta dibantu dengan pancaindra lainnya. Metode observasi digunakan untuk menggali data berupa fakta yang sebenarnya dilapangan dengan cara yang ilmiah untuk mendapatkan data akurat. Pada penelitian ini Peneliti menggunakan observasi teknik partisipasi pasif (Sugiyono, 2015). Peneliti datang ke tempat orang yang diamati, tetapi tidak ikut terlibat dalam kegiatan tersebut (Almanshur, 2017).

\section{Wawancara}

Wawancara adalah pertemuan antara dua orang yaitu antara peneliti dengan narasumber untuk melakukan pertukaran informasi dan ide dengan tanya jawab, sehingga dapat diambil makna dari topik tertentu (Sugiyono, 2015). Peneliti memilih wawancara semistruktur untuk memperoleh data. Akan tetapi sebelum mewawancarai, penulis terlebih dahulu melakukan penyusunan pedoman wawancara yang akan digunakan pada saat pelaksanaan wawancara yang sesungguhnya. Ketika pemilihan narasumber peneliti memilih narasumber yang memenuhi kriteria yaitu narasumber yang mengerti dengan masalah yang diteliti dan narasumber yang dipilih merupakan 
subjek yang masih aktif dalam lingkungan sasaran penelitian serta memiliki waktu untuk diminta informasi.

\section{Dokumentasi}

Dokumentasi adalah catatan suatu peristiwa yang berlaku. Dokumen dapat berupa tulisan, gambar, ataupun karya menumental dari seseorang (Sugiyono, 2015). Teknik mengkaji dokumen dalam penelitian ini yaitu mempelajari jurnaljurnal penelitian ilmiah dan skripsi mengenai tari dan etnomatematika serta foto-foto dan video yang didapatkan selama melakukan penelitian. Dokumen menjadi pelengkap data penelitian setelah melakukan observasi dan wawancara.

\section{Teknik Analisis Data}

Analisis data kualitatif adalah upaya yang dilakukan dengan jalan bekerja dengan data, mengorganisasikan data, memilah-milahnya menjadi satuan yang dapat dikelola, mensintesiskannya, mencari dan menemukan pola, menemukan apa yang penting dan apa yang dipelajari, memutuskan apa yang dapat diceritakan kepada orang lain (Moleong, 2017). Teknik analisis data yang digunakan sesuai dengan jenis data yang dikumpulkan dan pengumpulan data, analisis data penelitian ini bersifat interaktif. Langkah analisis dalam penelitian ini adalah analisis domain, analisis taksonomi, analisis komponen, dan analisis tema (Emzir, 2011).

\section{HASIL PENELITIAN DAN PEMBAHASAN}

a. Sejarah Tari Buyung

Tari buyung merupakan tari tradisional Kuningan yang sudah diakui pemerintah sebagai salah satu budaya yang dimiliki oleh daerah kabupaten Kuningan. Tari buyung berfungsi sebagai penyambutan tamu. Tamu-tamu pemerintahan yang berkunjung ke Kota Kuningan akan disambut dengan tarian buyung yang diperagakan oleh para penari di Pendopo Kuningan. Tari ini menjadi identitas masyarakat Kuningan khususnya Desa Cigugur.

Identitas yang dimiliki masyarakat Cigugur yakni mempunyai kebiasaan mengambil air ke sungai, danau, atau kolam. Hal tersebut semata-mata untuk memenuhi kebutuan mereka sehari-hari. Kebiasaan yang mereka lakukan sudah lama berakar dan menyatu dengan perilaku masyarakat yang suka tolong-menolong, dan gotong-royong tanpa memandang latar belakang status sosial maupun kepercayaan (agama) mereka.

Sejarah kehidupan di lereng gunung yang banyak mata air membuat banyak orang tua dulu yang membuat gerabah, tembaga untuk mengambil air ke mata air. Jadi, jika dilihat dari segi tempat maka banyak pengrajin buyung di sekitar wilayah Kuningan diantaranya Taraju, Sukahaji, Cigugur atau yang wilayahnya tidak jauh dari mata air kaki gunung. Kebiasaan zaman dulu yang gadis desa gunakan untuk mengambil air ke sungai, danau atau kolam dengan menggunakan buyung dari gerabah atau tembaga.

Pada tahun 1969 Ibu Emalia Djatikusumah istri dari seorang sesepuh adat Djatikusumah, seorang koreografer yang berdomisili di Cigugur ingin budaya atau kebiasaan warga Cigugur dalam mengambil air menggunakan buyung tidak hilang begitu saja. Semakin bertambahnya zaman kebiasaan tersebut semakin hilang, dari penggunaan alat dengan buyung ataupun kegiatannya. Oleh karena itu, untuk melestarikan kegiatan tersebut, beliau mengekspesikannya lewat gerakan tari. Hal itu bertujuan untuk mengenal dan 
mengenang masa-masa dulu. Hal ini dilakukan agar masyarakat yang menekuni tari buyung banyak, sehingga tari buyung akan terus eksis.

Awal pertama tari buyung diperkenalkan dalam pagelaran pada tahun 1970. Pada tahun tersebut yang menjabat menjadi bupati adalah Bapak Aruma, beliau menyukai seni. Oleh karena itu, paguyuban Paseban Tripancatunggal diberi kesempatan untuk membuat pagelaran seni. Bermacam-macam kesenian diciptakan, dimulai dari drama, tari, seni Cianjuran, sampai pencak silat juga ada.

Selain dalam pagelaran khusus seperti di atas, tarian buyung setiap tahunnya ditampilkan pada acara seren taun. Tarian tersebut menjadi tarian utama dalam susunan acaranya. Tari buyung wajib ditampilkan karena tari ini menjadi daya tarik masyarakat lokal maupun wisatawan dalam negeri. Sampai saat ini tarian buyung tiap tahun tidak pernah ketinggalan untuk ditampilkan di acara seren tahun.

b. Makna pada Bentuk Gerakan Tari Buyung

Tari buyung tidak hanya menampilkan gerakan tubuh semata, melaikan memiliki makna pada masing-masing bentuk gerakan yang diterapkan para penari. Adapun makna-makna yang terkandung dalam setiap gerakan dalam tari buyung ialah sebagai berikut:

1. Bentuk gerakan disaat penari bersimpuh di bawah

2. Bentuk gerakan disaat buyung diangkat dari kepala untuk mengambil air

3. Bentuk gerakan disaat naik kendi dan membawa buyung di kepala

4. Bentuk gerakan dalam gerak tangan bergandengan sejajar
Makna bersimpuh di bawah adalah harapan suatu bangsa di muka bumi mendapatkan tempat untuk kemerdekaan lahir batin dan memohon kepada tuhan yang maha kuasa. Selanjutnya, air melambangkan kehidupan. Dimana manusia tinggal, di sana manusia memerlukan air. Setelah itu, naik kendi dan membawa buyung dikepala sama maknanya dengan dimana bumi dipinjak di situ langit dijunjung. Membawa buyung di kepala haruslah mempunyai keseimbangan. Sama halnya dalam menjalankan kehidupan ini perlu diusahakan keseimbangan antara perasaan dan pikiran, sehingga selalu mengingat kepada kekuasaan tuhan yang maha esa. Terakhir, gerakan tangan bergandengan sejajar maknanya langkah seirama, seia sekata tidak membedabedakan antara perbedaan agama, bangsa, etnis, suku, ras semuanya ciptaan tuhan. Dengan dijalin rasa saling tolerasi dan rasa saling menghormati.

c. Identifikasi Gerakan Tari Buyung

Etnomatematika pada gerak tari buyung meliputi pola-pola frieze dan beberapa kajian geometri seperti dimensi satu, dimensi dua dan transformsi geometri. Penulis akan menjelaskan rinci etnomatematika pada setiap gerak tari buyung sebagai berikut:

1. Bentuk gerakan disaat penari bersimpuh di bawah

Perhatikan gerakan tangan penari berikut: 


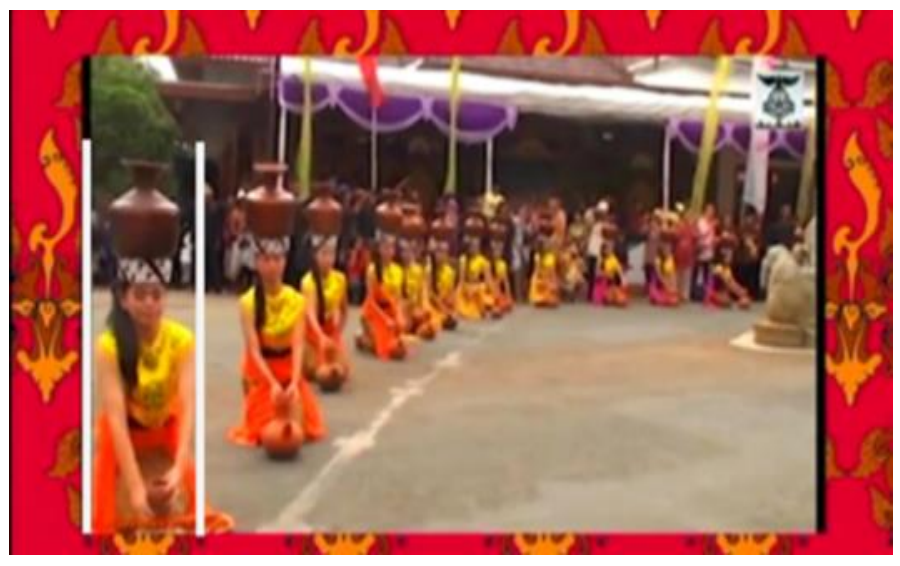

Gambar 17. Gerak Penari Bersimpuh di Bawah dengan Posisi Tangan Memegang Kendi ke Arah Depan

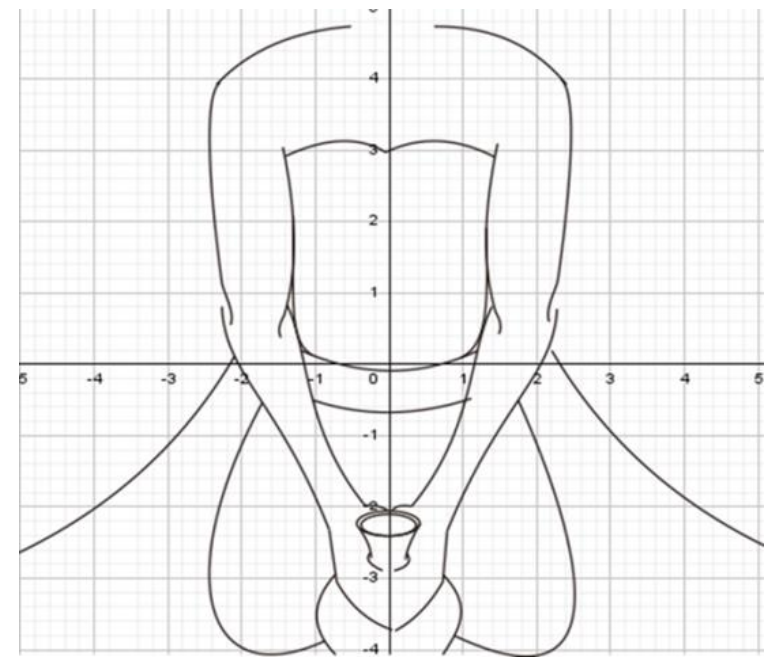

Gambar 18. Pola F3 pada Gerak

Penari Bersimpuh di Bawah dengan Posisi Tangan Memegang

Kendi ke Arah Depan
Gambar 17 adalah para penari duduk berlutut sambil nyuhun (menaruh di atas kepala) buyung di atas kepala dengan tangan diulurkan dan telapak tangan keduanya menggenggam kendi yang berada di depan penari. Gerakan ini diterapkan pada formasi yang pertama yaitu formasi medang kamulang dengan jumlah 18

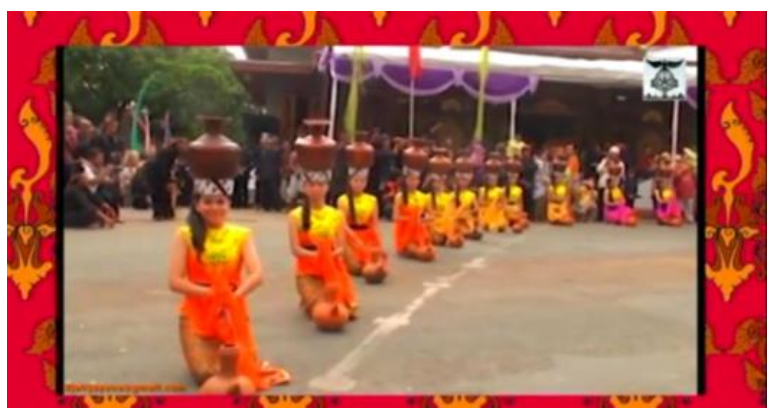

Gambar 19. Gerak Penari Bersimpuh dengan Posisi Tangan Bertumpang Tindih

Posisi selanjutnya, para penari duduk bersimpuh dan nyuhun buyung dengan posisi tangan bertumpang tindih. Posisi tangan tersebut terlihat tangan keduanya di depan pusar. Telapak tangan kanan menghadap ke kiri dengan ujung jari penari. Dengan demikian, jika dilihat dari bagian tangan penari ditemukan adanya refleksi vertikal, tetapi tidak ada refleksi horizontal seperti pada Gambar 18. Jadi posisi tersebut adalah pola frieze sidle atau pola F3.

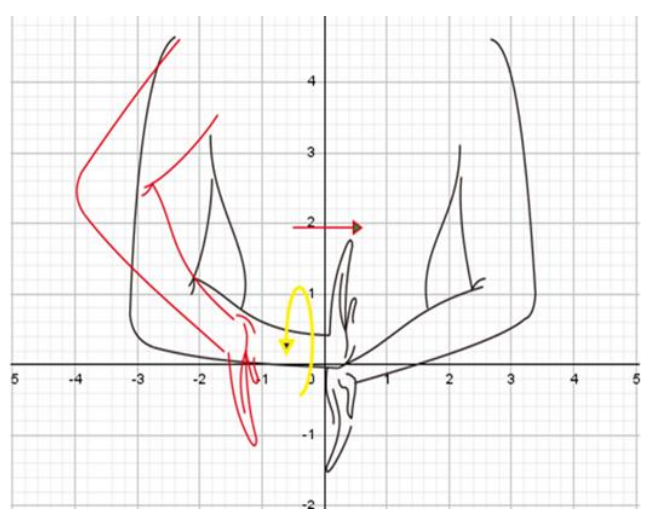

Gambar 20. Pola F5 pada Gerak Penari Bersimpuh di Bawah dengan Posisi Tangan Bertumpang Tindih

menunjuk ke atas sedangkan telapak tangan kiri menghadap ke kanan dengan ujung jari menunjuk ke bawah, dan kedua tangan tersebut saling bertumpang depan pusar. Posisi penari ini diterapkan pada formasi yang pertama yaitu formasi medang 
kamulang dengan jumlah 18 penari. Dengan demikian, posisi tersebut ditemukan adanya cermin geser, dan rotasi 180o seperti pada Gambar 20. Dengan

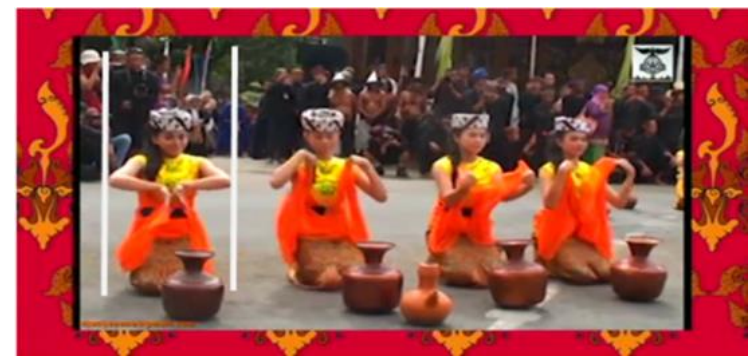

Gambar 21. Gerak Penari Bersimpuh di Bawah dengan Saling Menempelkan Kedua Punggung Tangan

Posisi para penari duduk berlutut dengan badan tegap kedepan dan kedua tangan diangkat sejajar dengan dada dan kedua telapak tangan saling membelakangi dengan jari menunjuk ke arah bawah. Dengan demikian, berdasarkan Gambar 22

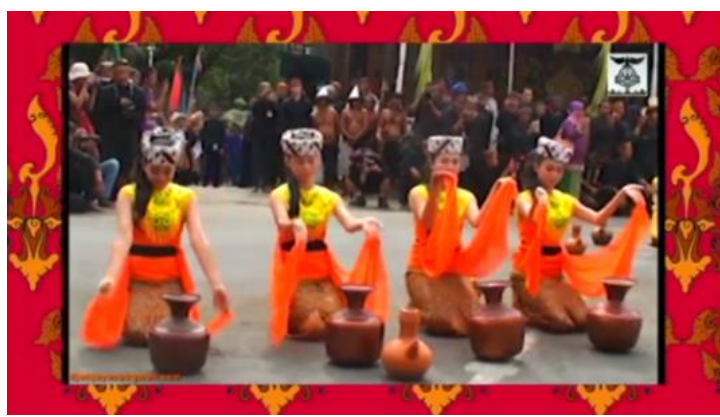

Gambar 23. Gerak Penari Besimpuh ke Bawah dengan Mengulurkan Tangan ke Depan

Gambar 23 adalah posisi duduk berlutut dengan kedua tangan diulurkan kedepan terbuka keatas dan sampai telapak demikian, posisi tersebut termasuk dalam pola Frieze spinning sidle atau pola F5.

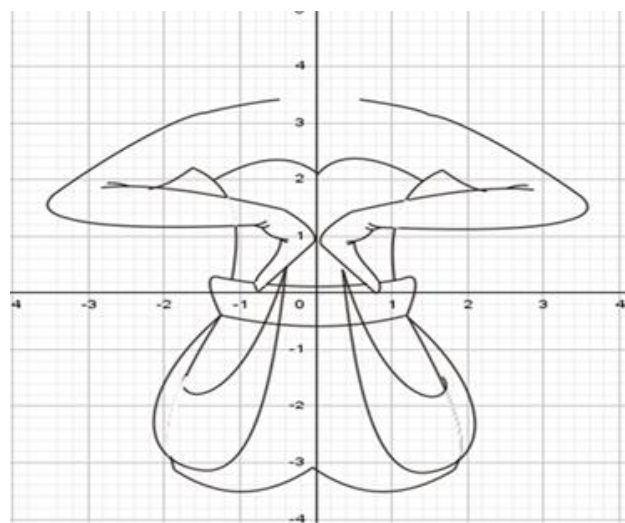

Gambar 22. Pola F3 pada Gerak Bersimpuh ke Bawah dengan Saling Menempelkan Kedua Punggung Tangan

bahwa posisi tersebut memiliki pencerminan vertikal akan tetapi, tidak terdapat pencerminan secara horisontal. Jadi, posisi ini juga merupakan pola frieze sidle atau pola F3.

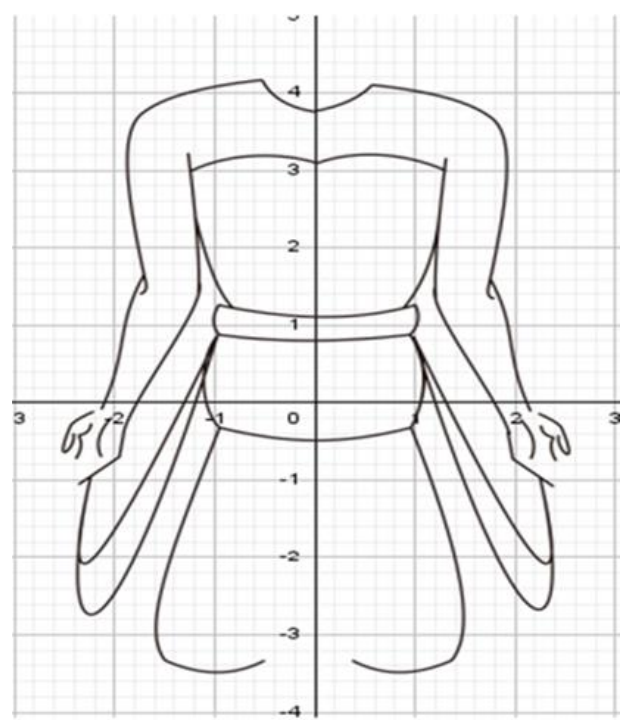

Gambar 24. Pola F3 pada Gerak Penari Bersimpuh ke Bawah dengan Mengulurkan Tangan ke Depan

tangan sejajar dengan lutut kaki. Pada posisi ini, ditemukan adanya refleksi vertikal, tetapi tidak ada refleksi horisontal 
seperti diilustrasikan pada Gambar 24. Jadi, posisi ini adalah pola frieze sidle atau pola

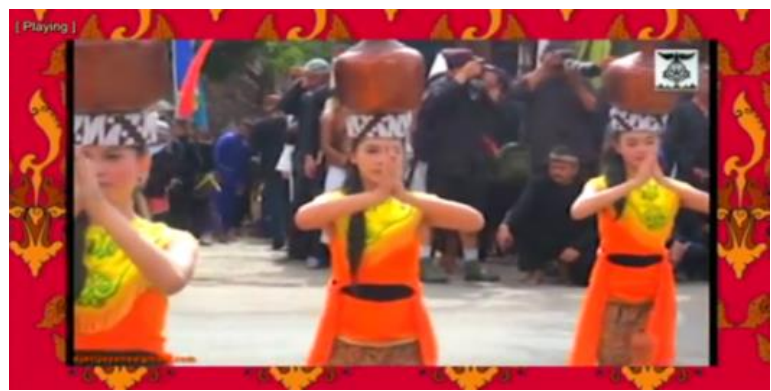

Gambar 25. Gerak Penari Bersimpuh ke Bawah dengan Posisi Tangan Menyembah

Gambar 23 adalah posisi duduk berlutut dengan kedua tangan diulurkan kedepan terbuka keatas dan sampai telapak tangan sejajar dengan lutut kaki. Pada posisi ini, ditemukan adanya refleksi

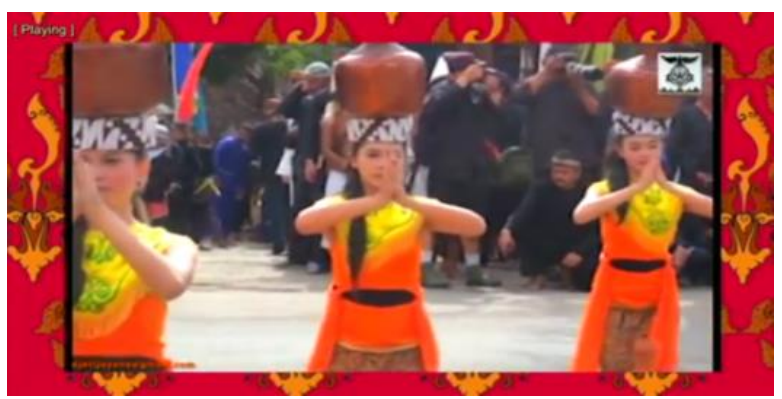

Gambar 25. Gerak Penari Bersimpuh ke Bawah dengan Posisi Tangan Menyembah
F3.

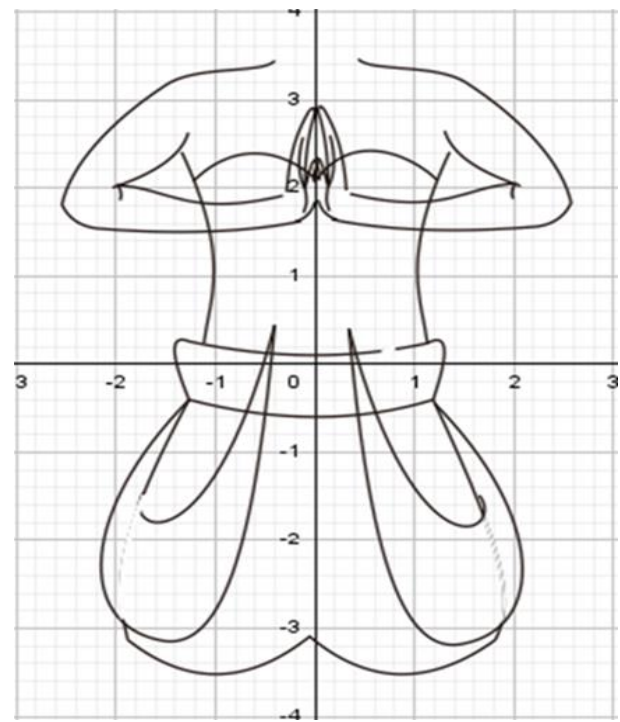

Gambar 26. Pola F3 pada Gerak Penari Bersimpuh ke Bawah dengan Posisi Tangan Menyembah

vertikal, tetapi tidak ada refleksi horisontal seperti diilustrasikan pada Gambar 24. Jadi, posisi ini adalah pola frieze sidle atau pola F3.

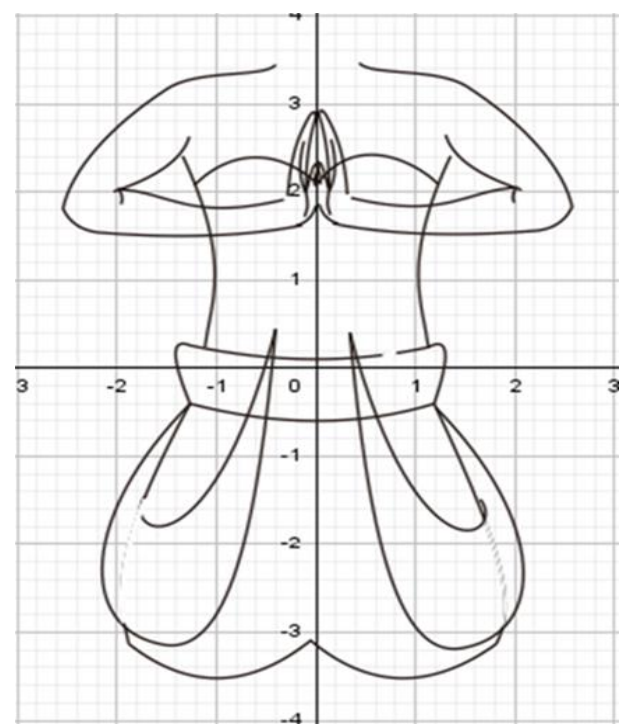

Gambar 26. Pola F3 pada Gerak Penari Bersimpuh ke Bawah dengan Posisi Tangan Menyembah 
Gambar 25 adalah posisi penari bersimpuh dengan gerakan tangan penari menyembah ke arah tengah. Pada saat tangan menyembah posisi telapak tangan saling menempel dengan tangan kanan menghadap ke arah kiri dan tangan kiri menghadap ke arah kanan dan diletakkan di depan dada. Posisi tangan penari seperti

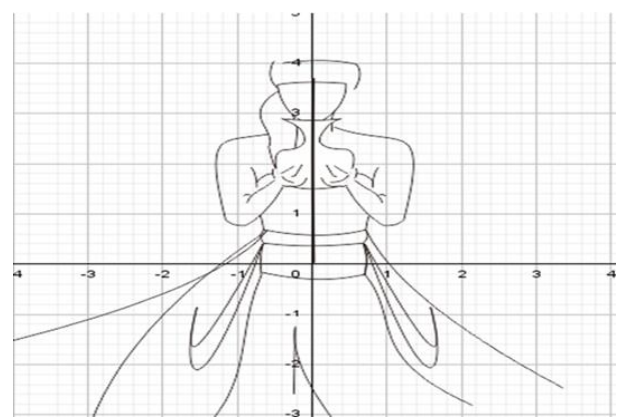

Gambar 27. Pola F3 pada Gerak Tari disaat Buyung Diangkat dengan Posisi Tangan Memegang Buyung di Depan Dada

Selanjutnya, merupakan posisi penari melakukan gerakan mengambil buyung di atas kepala dan mengangkatnya sejajar dengan dada. Pada bagian para penari berdiri dengan posisi melangkah (kaki kanan ke depan) dengan tangan mengangkat buyung dan kepala lurus kedepan seperti pada Gambar 27. Posisi penari diterapkan pada formasi yang pertama yaitu formasi nyakra bumi. Setelah itu, posisi penari jongkok, kaki kanan

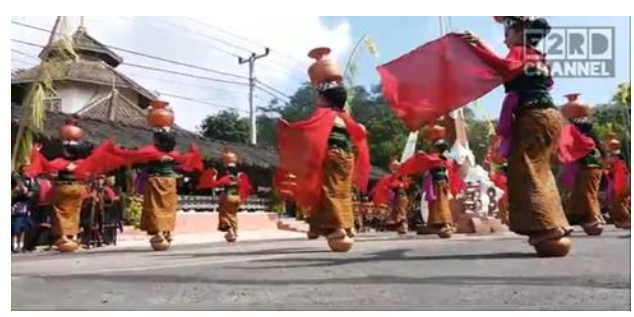

Gambar 29. Gerak Tari Disaat Naik Kendi dan Nyuhun Buyung dengan Posisi Tangan Direntangkan ke Samping yang diilustrasikan pada Gambar 26. Sehubungan dengan itu, membuat posisi ini termasuk dalam pola frieze Sidle atau pola F3 karena gerak pada posisi ini memiliki sifat translasi dan refleksi secara vertikal.

2. Bentuk gerakan disaat buyung diangkat dari kepala untuk mengambil air

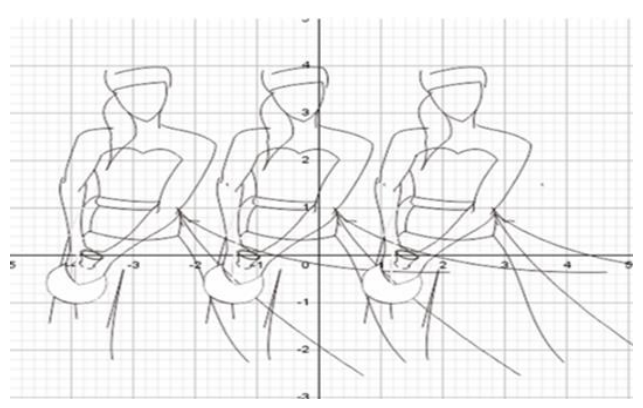

Gambar 28. Pola F1 pada Gerak Tari Disaat Buyung Diayunkan seperti Gerakan Mengambil Air

penari ke belakang dengan tangan mengayunkan buyung dan kepala menoleh ke kanan yang diilustrasikan pada Gambar 28 seperti gerakan mengambil air di danau. Dengan demikian, dalam posisi ini, tidak ditemukan adanya pencerminan vertikal, pencerminan horisontal, serta rotasi setengah putaran. Jadi, posisi ini adalah pola frieze hop atau pola F1.

3. Bentuk gerakan disaat naik kendi dan membawa buyung di kepala

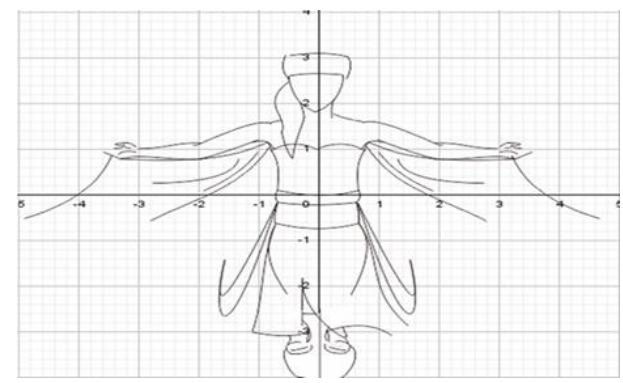

Gambar 30. Pola F3 pada Gerak Tari Disaat Kendi dan Nyuhun Buyung dengan Posisi Tangan Direntangkan ke samping 
Posisi penari pada Gambar 29 adalah para penari berdiri di atas kendi dan nyuhun buyung serta pandangan lurus ke depan serta tangan penari direntangkan. Pada ilustrasi Gambar 30 dapat ditemukan adanya cermin vertikal namun tidak terdapat pencerminan horisontal. Jadi posisi ini termasuk dalam pola frieze sidle atau pola F3.

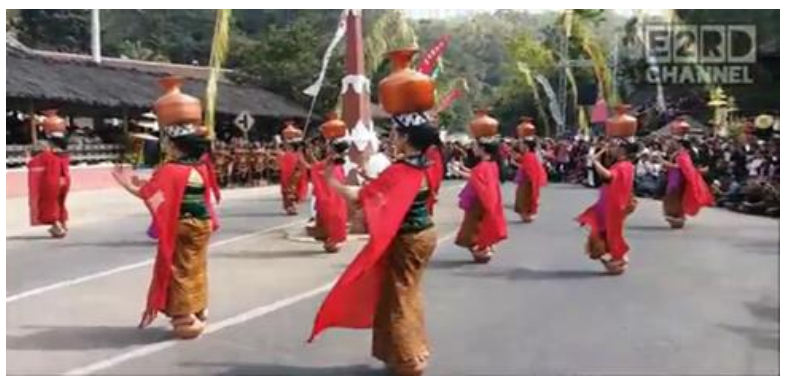

Gambar 29. Gerak Tari Disaat Naik Kendi dan Nyuhun Buyung dengan Posisi Tangan Direntangkan ke Samping

Posisi penari pada Gambar 29 adalah para penari berdiri di atas kendi dan nyuhun buyung serta pandangan lurus ke depan serta tangan penari direntangkan. Pada ilustrasi Gambar 30 dapat ditemukan

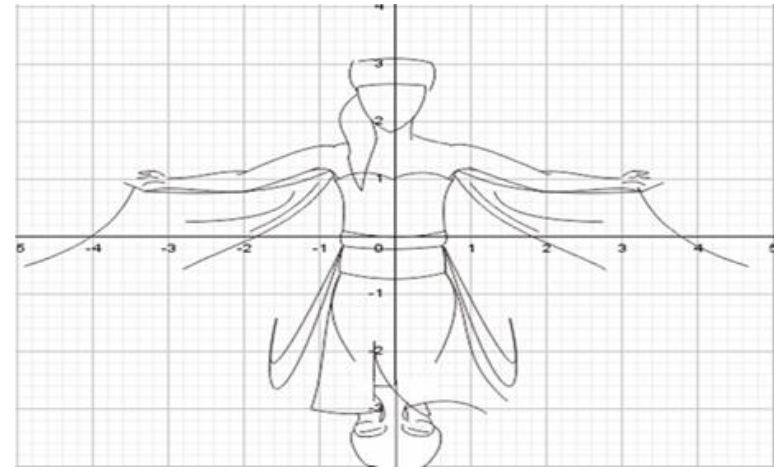

Gambar 30. Pola F3 pada Gerak Tari Disaat Kendi dan Nyuhun Buyung dengan Posisi Tangan Direntangkan ke samping

adanya cermin vertikal namun tidak terdapat pencerminan horisontal. Jadi posisi ini termasuk dalam pola frieze sidle atau pola F3.

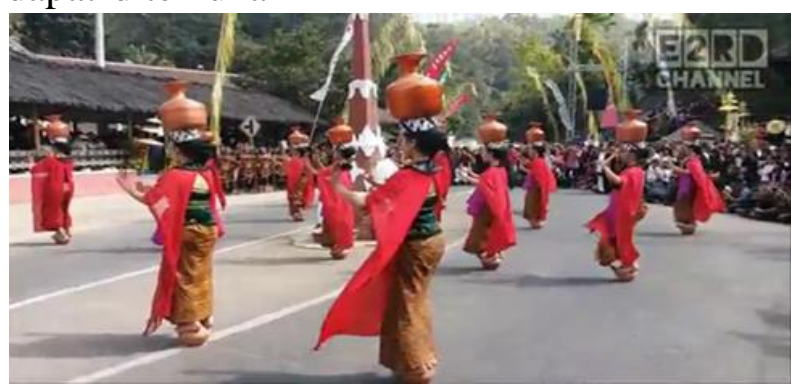

Gambar 31. Gerak Tari Disaat Naik Kendi dan Nyuhun Buyung dengan Posisi Tangan Direntangkan ke Depan

Pada posisi ini, terlihat pada Gambar 31 bahwa posisi penari tetap sama seperti pada Gambar 29 hanya gerakan tangan yang berbeda arah. Gerakan kedua tangan direntangkan kearah depan. Kedua telapak tangan sejajar dan searah dengan wajah masing-masing penari. Pada posisi tersebut ditemukan adanya cermin vertikal namun tidak terdapat pencerminan secara horisontal, sehingga posisi tersebut termasuk dalam pola F3.

4. Bentuk gerakan dalam gerak tangan bergandengan sejajar 


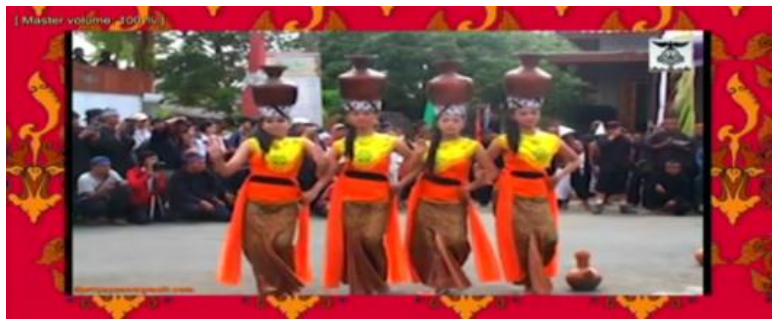

Gambar 32. Gerak Tangan Bergandengan

Sejajar

Posisi penari pada Gambar 33 adalah berdiri bergandengan menggunakan siku tangan kiri, dengan jari kiri mengepal ditempelkan ke bagian pinggang sebelah kiri. Kemudian, tangan sebelah kanan masuk kebagian dalam tangan kiri dan keluar bagian depan, Seakan-akan tangan kanan terkunci oleh siku tangan kiri. Posisi

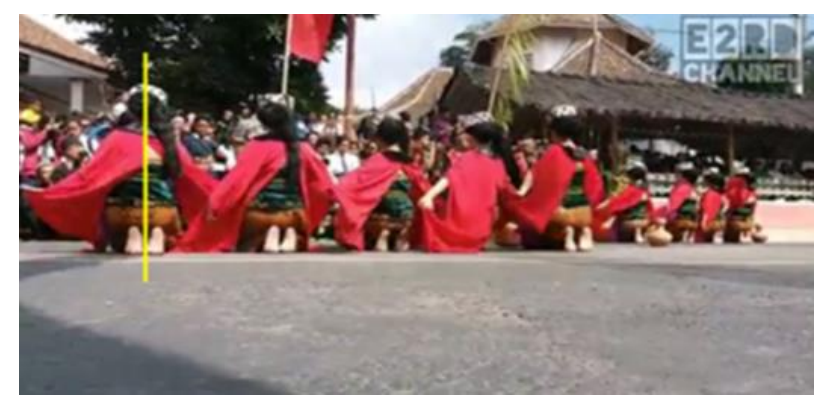

Gambar 34. Posisi Kaki pada Bentuk Tarian Disaat Bersimpuh di Bawah

Perhatikan gerakan pada bagian kaki penari. Posisi gerak kaki para penari duduk bersimpuh dengan jari-jari kaki tetap menekan ke tanah seperti terlihat pada Gambar 34. Dengan demikian, dalam posisi ini ditemukan adanya translasi dan refleksi secara vertikal, tetapi tidak ada refleksi horisontal seperti pada Gambar 35. Jadi, posisi ini adalah pola sidle atau pola F3.

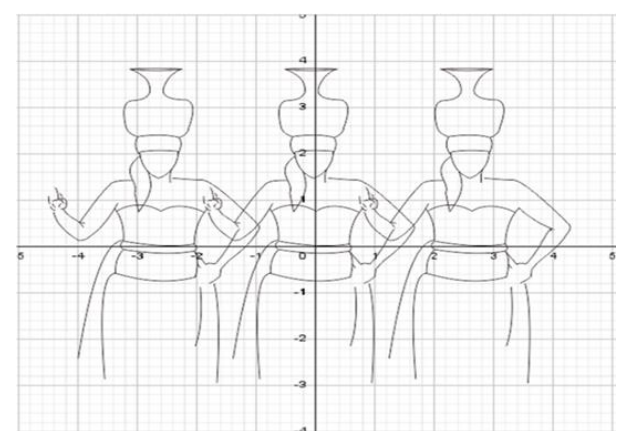

Gambar 33. Pola F1 pada Gerak Tangan Bergandengan Sejajar

penari ini diterapkan pada formasi yang pertama yaitu formasi lurus sejajar. Dengan demikian, dalam posisi ini tidak ditemukan adanya pencerminan vertikal, pencerminan horisontal, serta, rotasi setengah putaran. Jadi pada posisi ini adalah pola F1.

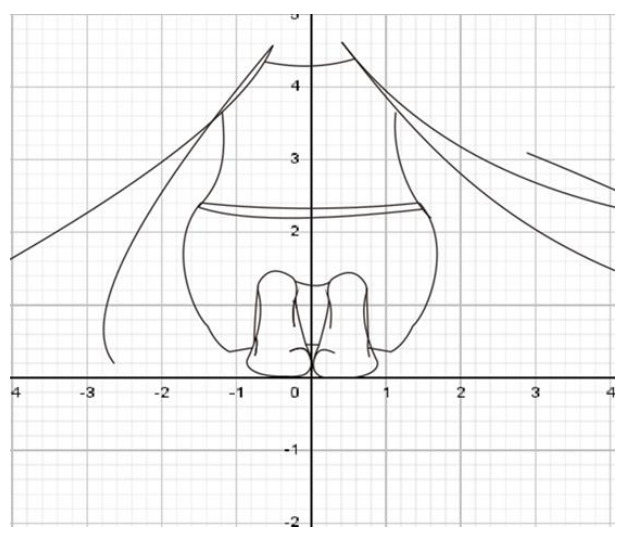

Gambar 35. Pola F3 pada Pola Kaki dengan Bentuk Tarian Disaat Bersimpuh di Bawah

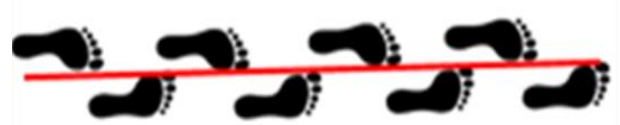

Gambar 36. Pola F1 Gerak kaki Penari Disaat Buyung Diangkat dari Kepala untuk Mengambil Air dengan Posisi Kaki Melangkah ke Depan

Bentuk gerakan pada bagian ini merupakan penerapan pada gerak penari 
berbaris lurus ke depan membentuk pola lantai garis lurus dan ketika penari membentuk formasi nyakra bumi. Hal ini menunjukkan bahwa dalam gerakan tari buyung menggunakan konsep geometri. Posisi garis lurus merupakan posisi awal gerakan tari buyung. Dalam konteks ini, yang harus diperhatikan yaitu gerakan tangan dan kaki penari. Terlihat pada Gambar 36 adalah gerakan kaki penari pada posisi awal dengan melangkahkan kaki berulang yang diawali kaki kanan ke depan selanjutnya mundur kaki kanan ke belakang. Pada gerakan tersebut ditemukan adanya translasi, tidak ditemukan adanya pencerminan vertikal maupun pencerminan horisontal melainkan ditemukan adanya refleksi geser. Jadi, posisi ini merupakan pola frieze step atau pola F2.

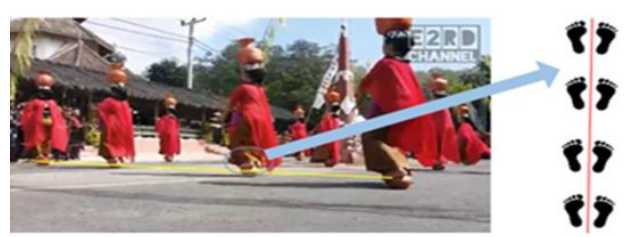

Gambar 37. Pola F3 pada Posisi Kaki Naik Kendi

Pada posisi penari pada Gambar 37, kaki penari berada di atas buyung dengan posisi kaki sejajar lurus ke depan. Pada posisi tersebut, ditemukan adanya cermin secara vertikal tidak terdapat pencerminan secara horisontal, sehingga posisi tersebut termasuk dalam pola frieze sidle atau pola F3.

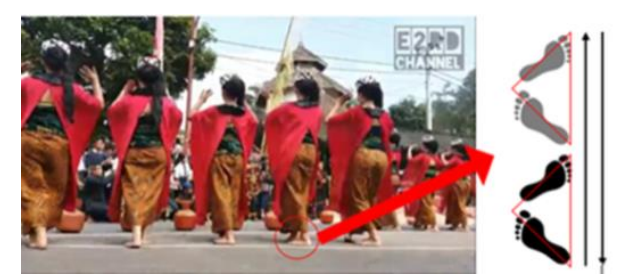

Gambar 38. Pola F1 pada Gerak Kaki Menyilang Arah ke Luar
Posisi gerakan pada Gambar 38 merupakan posisi para penari melangkahkan kaki ke depan dengan menyilangkan arah telapan kaki ke bagian luar. Posisi kaki tersebut terlihat akan membentuk pola segitiga sama kaki. Hal ini menunjukkan bahwa tari buyung menggunakan konsep geometri. Dengan demikian, posisi pengulangan pada gerakan ini, tidak ditemukan adanya pencerminan vertikal, pencerminan horisontal, serta rotasi setengah putaran. Sebagai kesimpulan, posisi ini adalah pola frieze hop atau pola F1.

Berdasarkan hasil analisis terkait pola Frieze Group dari gerakan tangan dan kaki diperoleh fakta bahwa Tari Buyung memiliki pola F1, F2, F3, dan F5. Jika diteliti lebih jauh, pola pada tari Buyung memiliki beberapa kesamaan gerak dengan tari Saman yang memiliki pola F1 dan F3 (Oktavianto et al., 2018). Dalam tari Saman asli Gayo yang paling banyak ditemukan adalah F1 sedangkan pada tari Saman Kreasi yang ditarikan oleh laki-laki dan perempuan adalah pola Frieze F3. Hal ini berbeda dengan pola pada Tari Buyung yang memiliki 4 pola yang berasal hanya dari penari wanita saja.

Selain itu, pada tari Buyung ini kaya akan berbagai gerakan yang melibatkan translasi, pencerminan vertikal, pencerminan horisontal, serta rotasi setengah putaran. Hal ini mengindikasikan bahwa tari Buyung memiliki kreativitas dan imajinasi yang sangat tinggi jika dibandingkan dengan tarian lain, misalnya tarian yang dipupulerkan oleh grup musik Crayon Pop dari Korea "Bar Bar Bar" yang hanya memiliki gerakan berupa translasi dan rotasi saja (Wahyudi \& Prisicillia, 2019). Oleh karena itu, selain sebagai sarana hiburan dan menjaga budaya serta 
kearifan lokal, tari - tarian dapat juga digunakan sebagai sarana untuk belajar (Lestari, 2019).

\section{SIMPULAN DAN SARAN}

\section{Simpulan}

Setiap gerakan tangan para penari dan gerakan antara penari satu dengan yang lainnya membuat gerakan tari buyung menjadi rapih dan menarik ternyata sesuai dengan Grup Frieze. Empat pola frieze pada tarian buyung diantaranya adalah pola frieze pada gerak penari disaat gerakan mengambil air, pola Frieze pada posisi kaki melangkah ke depan terdiri dari translasi, cermin geser yang disebut dengan pola frieze step atau pola F2. Pola frieze pada gerak penari disaat bersimpuh di bawah dengan posisi tangan memegang kendi ke arah depan dan Pola frieze pada gerak tari disaat bersimpuh di bawah dengan posisi tangan bertumpah tindih terdiri dari translasi dan rotasi $180^{\circ}$ yang disebut pola F5.

\section{Saran}

Penelitian yang dilakukan baru sebatas keterkaitan pola gerakan tari buyung dengan matematika saja, jika ada peneliti yang tertarik untuk lebih lanjut alangkah lebih baik jika membuat modul sebagai panduan bagi siswa dan penerus tari buyung Kuningan.

\section{DAFTAR PUSTAKA}

Abriyanti, E. (2019). Lunturnya Budaya Tradisional di Era Digital. Retrieved August 6, 2020, from https://www.harianbhirawa.co.id/luntu rnya-budaya-tradisional-di-era-digital/

Almanshur, M. (2017). Metode Penelitian Kualitatif. Yogyakarta: Ar-Ruzz Media.

Amalia, R., Muchyidin, A., \& Izzati, N.
(2019). The Implication of Relationship between Designing Woven Motive Skills and Logical Thinking in Mathematics Learning. Journal of Mathematical Pedagogy, 1(1), 1-8.

Anggito, A., \& Setiawan, J. (2018). Metodologi Penelitian Kualitatif.

Sukabumi: CV. Jejak.

Bungin, H. B. (2011). Penelitian Kualitatif. Jakarta: Kencana.

Desmawati, R. (2018). Eksplorasi Etnomatematika Pada Gerak Tari Tradisional Sigeh Penguten Lampung. UIN Raden Intan Lampung. https://doi.org/10.1051/matecconf/201 712107005

Drager, L. (2010). Geometric

Transformations and Wallpaper

Groups. Texas.

Emzir. (2011). Metode Penelitian Kuantitatif \& Kualitatif. Jakarta: Raja Grafindo.

Fauzi, F. (2018). Peran Pendidikan dalam Transformasi Nilai Budaya Lokal Di Era Millenial. INSANIA: Jurnal Pemikiran Alternatif Kependidikan, 23(1), 51-65. https://doi.org/10.24090/insania.v23i1. 2006

Fitriah, N., Muchyidin, A., \& Sahrodi, J. (2015). Implementasi Model Pembelajaran Matematika Berintegrasi Keislaman Dalam Meningkatkan Karakter Demokrasi Siswa. Eduma: Mathematics Education Learning and Teaching, $4(2)$. https://doi.org/10.24235/eduma.v4i2.3 4

Lestari, P. (2019). Eksplorasi Etnomatematika Pada Tari Tradisional Zapin Penyengat sebagai Sumber Belajar Matematika Sekolah. 
Universitas Maritim Raja Ali Haji.

Lukihardianti, A. (2018). Emil Luncurkan

Konsep Pendidikan Karakter Jabar

Masagi. Retrieved July 1, 2020, from https://republika.co.id/berita/nasional/

pemprov-jabar/18/12/04/pj7n0e423-

emil-luncurkan-konsep-pendidikan-

karakter-jabar-masagi

Moleong, L. J. (2017). Metode Penelitian

Kualitatif. Bandung: PT Remaja

Rosdakarya.

Muchyidin, A. (2016). Model Matematika

Kearifan Lokal Masyarakat Desa

Trusmi Dalam Menjaga Eksistensi

Kerajinan Batik Tulis. JES-MAT, 2(1).

Munjiatun. (2018). Penguatan Pendidikan

Karakter. Jurnal Kependidikan, 6(2),

334-349.

https://doi.org/10.24090/jk.v6i2.1924

Nahak, H. M. . (2019). Upaya Melestarikan

Budaya Indonesia Di Era Globalisasi.

Jurnal Sosiologi Nusantara, 5(1), 65-

76.

https://doi.org/10.33369/jsn.5.1.65-76

Oktavianto, R. G., Raden Rara Lucia Hesti

Ratnasari, \& Agty Devina Puspitasari.

(2018). Frieze group dalam tari saman.

In Seminar Nasional Matematika dan

Pendidikan Matematika (pp. 72-77).

Purworejo:

Universitas

Muhammadiyah Purworejo.

Pemerintah Kabupaten Kuningan. (2019).

Seni Budaya. Retrieved July 1, 2020,

from

https://www.kuningankab.go.id/wisata

-budaya/seni-budaya

Reinha, N. (2019). Tari Buyung Refleksi

Untuk Generasi Zaman Now.

Retrieved July 1, 2020, from https://www.reinha.com/2017/12/tari-

buyung-refleksi-untuk-generasi-

zaman-now/

Royyani, M. (2008). Upacara Seren Taun
Di Cigugur, Kabupaten Kuningan, Jawa Barat: Tradisi Sebagai Basis Pelestarian Lingkungan. Indonesian Journal of Biology, 4(5), 399-415.

Sahroni, D. (2017). Pentingnya Pendidikan Karakter Dalam Pembelajaran.

Prosiding Seminar Bimbingan Dan Konseling, 1(1), 115-124. Retrieved from

http://pasca.um.ac.id/conferences/inde x.php/snbk

Sandhi, N. S. A., Trapsilasiwi, D., Yudianto, E., Suharto, \& Sugiarti, T. (2018). Etnomatematika Pola Tarian Jejer Jaran Dawuk Banyuwangi Sebagai Inspirasi Pengembangan Paket Tes Geometri. Kadikma, 9(3), 160-170.

Sugiyono. (2015). Metode Penelitian Pendidikan: Pendekatan Kuantitatif, Kualitatif, dan $R$ \& D. Bandung: Alfabeta.

Suharyanto. (2018). Tari Buyung dan Penjelasannya. Retrieved July 1, 2020, from https://ilmuseni.com/senipertunjukan/seni-tari/tari-buyung

Suherman, A. (2018). Jabar Masagi: Penguatan Karakter Bagi Generasi Milenial Berbasis Kearifan Lokal. Lokabasa, $\quad 9(2), \quad 107$. https://doi.org/10.17509/jlb.v9i2.1567 8

Sumaryati. (2016). Manajemen Pendidikan Karakter. Tarbawiyah, 13(2), 205220.

https://doi.org/10.21831/jpk.v0i3.2752

Sutarto, D. (2016). Kearifan Budaya Lokal Dalam Pengutan Tradisi Malemang Di Tengah Masyarakat Modernisasi Di Sungai Keruh Musi Banyuasin Sumatera Selatan. Jurnal Dimensi, 5(3), 2-6. https://doi.org/10.33373/dms.v5i3.54 
Thonthowi. (2008). Pendidikan dan Tradisi (Menakar Tradisi Pendidikan Pesantren). Tadris, Vol 3 No 2, 150165.

Umble, R. N., \& Han, Z. (2014). Transformational plane geometry. Transformational Plane Geometry. https://doi.org/10.1201/b17787

Wahyudi, A. R. D., \& Prisicillia, C. E. D. (2019). Unsur Matematika dalam Gerakan Tari Bar Bar Bar oleh Crayon Pop. Prosiding Sendika, 5(2), 21-27.

Widi, H. (2019). Seren Taun, Ritual Seserahan yang Menyimbolkan Persatuan dan Kesatuan. Retrieved
July $\quad 1, \quad 2020, \quad$ from https://www.cendananews.com/2019/0 8/seren-taun-ritual-seserahan-yangmenyimbolkan-persatuan-dankesatuan.html 